\title{
Protection against occupational exposure to natural sources*
}

\author{
A. RANNOU**
}

(Manuscrit reçu le 18 novembre 1997, révisé le 31 janvier 1998, accepté le 5 mars 1998)

ABSTRACT All forms of life are unavoidably exposed to radiation from natural sources. Over the past decade, a growing awareness with regard to potential hazard incurred at work as a consequence of this natural radioactivity has emerged. Considering that this exposure should reasonably be regarded in certain circumstances as being the responsibility of operating management, the Internal commission on radiological protection (ICRP) provided some practical guidance on good practices in this field in its recent publications. One key question however remains to identify properly the situations in which exposure from natural sources should be included as part of occupational exposure and possibly subject to the same degree of control as those from artificial radiation sources. This paper intends to assess the scope of the problem and to review recent data reported on exposure which may occur in different workplaces due to natural sources: radon, material with elevated levels of natural radionuclides and cosmic radiation.

RÉSUMÉ Radioprotection des travailleurs exposés aux sources naturelles de rayonnements.

Toute forme de vie sur terre est inévitablement soumise à l'exposition aux sources naturelles de rayonnements. Au cours des dernières années, une préoccupation grandissante à l'égard du risque potentiel lié à cette exposition naturelle reçue sur les lieux de travail a vu le jour. Considérant que cette exposition peut raisonnablement être perçue dans certaines circonstances comme étant de la responsabilité des employeurs, la Commission internationale de protection radiologique (CIPR) a apporté quelques guides de bonnes pratiques sur le sujet dans ses récentes publications. L'une des questions-clés à résoudre néanmoins est d'identifier correctement les situations pour lesquelles l'exposition due aux sources naturelles de rayonnements doit être incluse dans l'exposition professionnelle et être éventuellement soumise au même degré de contrôle que pour les sources artificielles. Ce papier tente d'évaluer l'étendue du problème et d'apporter une analyse des données récentes sur l'exposition qui peut se produire sur les lieux de travail en relation avec différentes sources : radon, matériaux riches en radioéléments naturels, rayonnements cosmiques.

\footnotetext{
Cet article a été préparé à l'occasion d'un cours donné au BfS (Berlin) le 16 octobre 1997 dans le cadre du IAEA Regional Basic Professional Training Course on Radiation Protection, Berlin, 1 Sept. - 24 Oct. 1997

** Institut de protection et de sûreté nucléaire, département de protection de la santé de l'homme et de dosimétrie, service de dosimétrie, IPSN BP6 - 92265 Fontenay-aux-Roses Cedex, France
} 


\section{Introduction}

Natural radiation is ubiquitous in the environment. Attention was first directed towards the highest exposures and to those cases where actions to reduce or limit exposure were most likely to be effective. It was early recognised that the high mortality rate from lung cancer among uranium miners could be attributed to radon exposure. That is why implementation of radiation protection principles against occupational exposure in uranium mines and regulatory requirements to monitor and record these exposures began several decades ago.

Later on, it was found that enhanced levels of natural background radiation may be encountered in many other occupational settings, especially in non-uranium underground mines, in natural caves, medical treatment areas in spas, and similar environments. More recently, the exposure of airplane crews has also raised concerns.

The general principles that limit occupational exposure against ionizing radiation should, therefore, it is now thought, be extended to situations that are not directly associated with nuclear activities but which involve natural hazards.

The ICRP has paid special attention to this in its publications 60 (ICRP, 1991), 65 (ICRP, 1993) and 75 (ICRP, 1997). IAEA Basic Safety Standards issued in safety series $\mathrm{N}^{\circ} 115-\mathrm{I}$ (IAEA, 1994) and european directive 96/29/Euratom (European Union, 1996) are based on the radiation protection recommendations developed by ICRP.

\section{Scope of the problem}

Persons in a wide variety of work situations are exposed to ionizing radiation either from natural or artificial sources. For regulatory purposes, however, we must distinguish exposures that should be controlled by the operating management from the exposure arising from the general radiation in the environment in which all human being must live. Thus, occupational exposure to ionising radiation, regardless of its source, is generally defined restrictively as "exposures incurred at work as the result of situations that can reasonably be regarded as being the responsibility of the operating management" (ICRP, 1991).

Of the different components of natural source radiation, potassium-40 in the body, cosmic rays at ground level and radionuclides in undisturbed earth crust are clearly outside any reasonable scope of control. They are said to be excluded from the system of regulation. On the other hand, however, the specific situations that should be included within the system of regulatory control are not always unequivocally identifiable. ICRP has provided some practical 
guidance and, in particular, recommended in its publication 60 that exposures from natural sources be considered as occupational only in the following cases (ICRP, 1991):

(1) Operations in workplaces where the regulatory agency has declared that radon needs attention and has identified the relevant workplaces.

(2) Operations with and storage of materials not usually regarded as radioactive, but which contain significant traces of natural radionuclides and which have been identified by the regulatory agency.

(3) Operation of jet aircraft.

(4) Space flight.

Exposure during space flight is a very specific problem and may be thus considered as being out of the scope of the general principles for the radiation protection of the workers. It will not be treated further in this paper.

ICRP in its publication 75 has also recommended that, in some specific circumstances, regulatory agencies consider, as well, the gamma radiation from natural radioactive substances (ICRP, 1997). These cases require further clarification and the principles relevant to their control need further development. ${ }^{(1)}$

All things considered, any exposure to natural sources at work may be of concern and taken into account in occupational exposure, unless the sources have been formally excluded (see above) or exempted from regulatory control. According to ICRP publication 60, there is two grounds for exempting a source or an environmental situation. One is that the source gives rise to small individual doses and small collective doses. The other is that no reasonable control procedures can achieve significant reductions in those doses (ICRP, 1991).

Workers' exposure from natural sources of radiation, with a few exceptions, has generally not been subject to the same degree of control as that from manmade sources. The few exceptions are exposure in uranium mines and mills, and during practices involving the handling of purified forms of naturally occurring radioactive substances. In places where control of occupational exposure has not yet been introduced, there is a paucity of data about individual doses: our knowledge of the situation must be improved.

(1) At the time of the endorsement of the Basic Safety Standards of IAEA, the available quantitative recommendations of the ICRP for protection against exposure to natural sources were confined to radon. It was therefore decided by IAEA that the general obligations for practices concerning protection against natural sources, which is normally a chronic exposure situation, should be subject to radon, the exposure of other natural sources being expected to be dealt with by exclusion or exemption of the source or otherwise at the discretion of the regulatory authority. 


\section{Radon at work}

ICRP notes in its publication 65 that it is sometimes difficult to distinguish clearly between radon concentrations that should be treated as due to a practice (and consequently subject to control) and those that should be considered to be due to an existing situation for which intervention may be needed (ICRP, 1993).

In its publication 65 , the commission recommends that exposure to radon should be excluded from the system of protection and treated separately. Specifically, it recommends the adoption of an action level to define workplaces in which intervention should be undertaken to reduce radon exposures. Unless otherwise stated by the regulatory authorities, workplace radon exposure that is below the action level should not be treated as occupational. When simple countermeasures do not reduce the radon concentrations below the action level, the commission's system of protection should be applied to the practice. A schematic diagram of the decision logic is given in Figure 1.

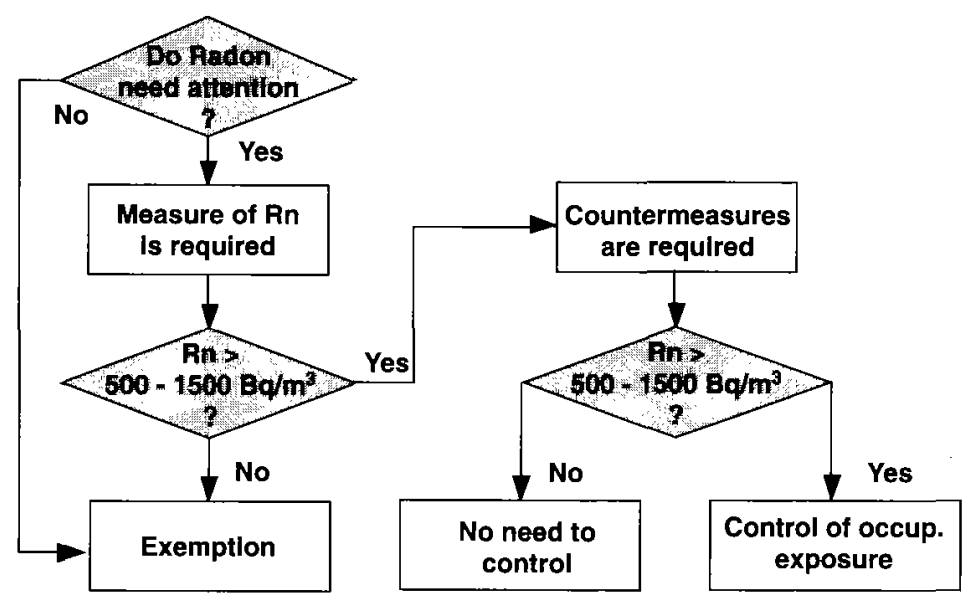

Fig. 1 - Schematic diagram derived from ICRP 75 giving the approach for the occupational radon risk management.

ICRP recommends that the action level for intervention should be applied to the effective dose and should be in the range of 3 to $10 \mathrm{mSv} \mathrm{y}^{-1}$. Assuming an occupancy of 2000 hours a year and an equilibrium factor of 0.4 , this criterion sets an action level for long-term average radon concentration within the range of 500 to $1500 \mathrm{~Bq} \mathrm{~m}^{-3}$. 


\subsection{Uranium mining and milling}

Occupational exposure associated with uranium mining and milling activities has been under consideration for several decades and is already subject to control. In 1991, about 90000 underground miners were engaged in mining uranium ore (UNSCEAR, 1993). OECD, AEN and IAEA (OECD, 1994) have estimated that annual global production of uranium in the period 1990-1994 decreased gradually from $50129 \mathrm{t}$ to $30948 \mathrm{t}$. Production has, however, increased substantially since 1995 in several countries.

In mining and milling uranium ore, workers can receive both external and internal exposure.

In underground mines, external exposure comes from beta and gamma radiation emitted from the walls and extracted ore within the gallery. The most important contribution to the external dose rate comes from bismuth-214 and lead-214, both of which are short-lived decay products of radon-222. Typically, the external dose rate in the centre of a gallery in an underground mine containing $0.1 \%$ uranium ore is on the order of $5 \mu \mathrm{Gy} \mathrm{h}^{-1}$. Much higher ambient dose rates, however, - in the range of 50 to $200 \mu \mathrm{Gy} \mathrm{h}^{-1}$ - may be measured in galleries during operations (Bernhard, 1995).

Internal exposure arises from the inhalation of radon gas and its decay products and from long-lived alpha emitters in ore dust. These long-lived radionuclides may contribute critically to internal dose, particularly in dusty workplaces with a uranium content in ore above $0.5 \%$.

On the whole, it is the radon "risk" that is most important in underground mines with uranium vein deposits. In these mines, radon contributes 50 to $75 \%$ of the total exposure. In mines with sedimentary type deposits and operating with a high degree of mechanization, inhalation of long-lived dust represents the greater part of exposure. This schema is also true for open pit mines (Bernhard, 1995).

The total exposure rate (TER) represents the sum of the 3 risks described above and may be defined as follows:

$$
\mathrm{TER}=\frac{H_{\mathrm{p}}}{20 \mathrm{mSv}}+\frac{I_{\mathrm{udd}}}{800 \mathrm{~Bq}}+\frac{J_{222_{\mathrm{Rn}}}}{17 \mathrm{~mJ}}
$$


where

$H_{\mathrm{p}}=$ annual personal dose equivalent due to external radiation (mSv)

$I_{\mathrm{u} . \mathrm{d}}=$ annual incorporation of long-lived uranium ore dust $(\mathrm{Bq})$

$J_{222 \mathrm{Rn}}=$ annual inhaled potential alpha energy from radon-222 progeny $(\mathrm{mJ})$.

Each term on the right side of expression (1) must be less than 1, and the TER must be less than 1 , over one year.

Where a significant risk may arise from radon-220, a further term must be taken into account, so that TER is expressed as:

$$
\mathrm{TER}=\frac{H_{\mathrm{p}}}{20 \mathrm{mSv}}+\frac{I_{\mathrm{u} . \mathrm{d} .}}{800 \mathrm{~Bq}}+\frac{J_{222} \mathrm{Rn}}{17 \mathrm{~mJ}}+\frac{J_{220_{\mathrm{Rn}}}}{51 \mathrm{~mJ}} .
$$

Miners' internal exposure may be reduced with standard techniques: drilling with water, watering down material and wall face after firing and during loading, good secondary ventilation system, frequent change of filters in the exhaust fans, good quality primary air with a forced system. Where high-grade ore is present, external exposure due to gamma radiation may also be reduced by shielding engines, removing personnel from "hot" areas, and similar measures. The mechanization of underground activities and remote or tele-operation both help prevent exposure levels that are too high.

Individual monitoring with integrated dosimetry systems, ambient monitoring based on "on line" measurements, and ALARA procedures also contribute to limiting exposure. There remains, however, a risk of exceeding individual annual dose limits in underground mines. For example, of the 1460 underground miners who were monitored in the facilities operated by GOGEMA in 1992, 24\% received more than $20 \mathrm{mSv}$, and $1.4 \%$ received more than $50 \mathrm{mSv}$ (Bernhard, 1995).

\subsection{Radon in other settings than $U$-mines}

Significant radon concentrations may be found in other types of workplaces, including non-uranium mines, some other underground sites and some ordinary buildings (offices, shops, schools...).

\subsubsection{Underground mines}

In 1991, there were an estimated 3.8 million coal miners and 0.6 million other underground miners in non-uranium mines worldwide (OECD, 1994) Their exposure to radon progeny depends on a number of factors including type of mine, its geology, and working conditions, particularly ventilation. 
The worldwide annual collective dose from the inhalation of radon progeny in underground mines (excluding uranium mines) was estimated by UNSCEAR (UNSCEAR, 1993) to be approximately 5300 man.Sv, with roughly 1500 man.Sv (about 30\%) in coal mines and the remainder in some other mines such as tin, gypsum, potash, etc. The world-wide average annual effective dose was estimated to be about $0.4 \mathrm{mSv}$ in coal mines and about $5 \mathrm{mSv}$ in other mines.

\subsubsection{Other underground workplaces}

The main below-ground workplaces where high radon exposure may occur are radon spas, subways, show caves and tourist mines, and underground water treatment works and storage facilities.

In radon spas, the presence of radon is held to be necessary. Radioactive thermal springs have been used for centuries for various medical cures. In general, occupational exposure to radon in therapy rooms depends on the treatment procedures, which control temporal variation of radon and radon daughter levels. The water used contains radon in concentrations that typically range between 10 and $1000 \mathrm{kBq} \mathrm{m}^{-3}$. Radon is distributed in air within the buildings by the physical processes of diffusion and air circulation. In Austria, occupational exposure in the special case of the "Thermal Gallery" treatment facility in Badgastein has been controlled by the National Occupational Health and Safety Authority (Lettner et al., 1996). The radon concentration in air varied widely $\left(10-3300 \mathrm{~Bq} \mathrm{~m}^{-3}\right)$, depending on the specific site. Annual effective doses were estimated in the range of 9.4-32 $\mathrm{mSv} \mathrm{y}^{-1}$ for workers in the inhalation facilities. Szerbin (Szerbin, 1996) observed similar situations in Hungary: the yearly mean radon concentration in air is several $\mathrm{kBq} \mathrm{m}^{-3}$ in the Rudas spa treatment facilities, and the mean annual effective dose received by the staff has been estimated in the range of $8-34.8 \mathrm{mSv} \mathrm{y}^{-1}$. In Italy, Sciocchetti (Sciocchetti et al., 1990) reported results of a national survey of radon and radon-daughter air concentrations measured at spas on the Isle of Ischia and in other areas of the country. The natural spring waters on the Isle of Ischia, which contain from 50 to $19000 \mathrm{kBq} \mathrm{m}^{-3}$ of radon, are among the most radioactive in the world. Radon concentration in air ranges from 0.44 to $514 \mathrm{kBq} \mathrm{m}^{-3}$. Annual occupational effective doses have been calculated to range from 0.01 to 60.5 $\mathrm{mSv} \mathrm{y}^{-1}$.

Some measurements have been carried out in show or tourist caves. Radon levels, while posing no risk to members of the public visiting the caves, may present a potential problem for the full-time staff who spend extended periods conducting tours or carrying out maintenance inside the caves. Preliminary estimates of the exposure of Australian cave guides were derived with the assumption that each guide spent $1000 \mathrm{~h} \mathrm{y}^{-1}$ underground (Solomon et al., 1996) This study suggested that most guides of these caves receive more than $5 \mathrm{mSv}$ in a year. In Ireland, mean radon concentrations recorded in three show caves varied 
between 2040 and $7400 \mathrm{~Bq} \mathrm{~m}^{-3}$. Effective doses to tour guides ranged from 2.0 $\mathrm{mSv}$ to $7.4 \mathrm{mSv}^{-1}$ while tourists received only between 3 and $12 \mu \mathrm{Sv}$ per tour (Duffy et al., 1996).

Better assessment of the real extent of the problem requires further data.

\subsubsection{Above-ground exposures}

The spectrum of places where radon can present an occupational hazard is large and includes such buildings as shops, schools and offices. In general, workplaces concerned by this issue are likely to be found in the same areas as those where high radon concentrations have already been detected, in dwellings or mines. For example, the Canadian province of Saskatchewan, where high-grade uranium ore mining is an important industry, has identified a number of office buildings or other workplaces with relatively high radon concentrations. It appears that these high levels of radon are associated with the take-up of radium from water on the outside of grains of clay as a result of ion exchange processes, and not necessarily with abnormally high concentrations of radium in the soil (Brown, 1990).

From a pilot study in the United Kingdom, Clarke (Clarke, 1996) estimated that there may be between 5000 and 100000 workplaces in OECD countries above an action level in the ICRP range, i.e., 500-1500 $\mathrm{Bq} \mathrm{m}^{-3}$.

\section{Materials with elevated levels of natural radionuclides}

A substantial worldwide industry including mining and milling activities involves material with relatively high concentrations of uranium and thorium, either for their own sake or for the materials that occur with them (metals and phosphates). In addition, during the processing of some materials, concentrations of natural radionuclides, often out of secular radioactive equilibrium with their parents or daughters, may increase. For example, radioactivity can build up in ore smelters, in plants that process calcium phosphate during the production of phosphoric acid and fertilizers, in the pipes and valves of oil platforms and refining facilities (OECD, 1994). This list, which is far from being exhaustive, includes such materials (with main radionuclides in brackets) as: fluorspar ${ }^{226} \mathrm{Ra}$ ), zircon ( $\mathrm{U}$ and Th), monazite ( $\mathrm{U}$ and $\mathrm{Th}$ ), and phosphate (U). These materials give rise to both internal exposure, particularly during dusty operations (e.g., cleaning or maintenance), and to external exposure. For materials with activity concentrations between 1 and $10 \mathrm{~Bq} \mathrm{~g}^{-1}$ of parent radionuclides (i.e., about 10-100 normal concentration in earth's crust), annual effective doses to workers are on the order of 1-2 $\mathrm{mSv}^{-1}$ from internal and external exposure (OECD, 1994). In one factory 
in Italy, for example, which produces refractory materials with zircon sand containing about $3 \mathrm{~Bq} \mathrm{~g}^{-1}$ of ${ }^{238} \mathrm{U}$ and $0.8 \mathrm{~Bq} \mathrm{~g}^{-1}$ of ${ }^{232} \mathrm{Th}(\mathrm{OECD}, 1994)$, doses have been estimated at about $5 \mathrm{mSv} \mathrm{y}^{-1}$.

Consequently, ICRP in its Publication 75 (ICRP, 1997) recommends that regulatory agencies choose activity concentrations of parent nuclides within the range $1-10 \mathrm{~Bq} \mathrm{~g}^{-1}$ as a criterion for determining whether these materials should be regarded as responsible for occupational exposure. ICRP notes that a similar range has been derived in the calculation of exemption levels by the Commission of the European Communities (CEC, 1993).

Where bulk quantities or dusty processes are involved, consideration will need to be given to whether exposure can be reduced in a cost-effective manner, e.g., using respiratory protective equipment or improving ventilation.

\section{Aircrew exposure to cosmic radiation}

Airplane crew members and others who fly frequently may be exposed to elevated levels of cosmic radiation of galactic and solar origin and of secondary radiation produced in the atmosphere or in aircraft structure. Total exposure on a given flight depends on the particular path taken through the atmosphere in terms of altitude, geomagnetic latitude, and aircraft speed, i.e., the duration of exposure at various altitudes and latitudes. Exposure associated with any flight path may also vary with time, particularly with phases of the solar activity cycle. Higher dose rates are observed during periods with lower solar activity. This opposite effect may be explained as a result of the modulation of the magnetosphere by the solar activity.

Measurements carried out during various flights indicate that the effective dose rate at subsonic altitudes $(8-12 \mathrm{~km})$ is within the range of 1 to $3 \mu \mathrm{Sv} \mathrm{h}^{-1}$ at low latitudes (equator) and within the range of 3 to $10 \mu \mathrm{Sv} \mathrm{h}^{-1}$ at higher latitudes $\left(>50^{\circ}\right.$ ), where high-LET particles (i.e., essentially neutrons) contribute roughly $50 \%$ of the total effective dose rate on board subsonic aircrafts.

The analysis by O'Brien (O'Brien et al., 1996) showed that the equivalent doses from galactic radiation received on 32 conventional flights on a wide variety of routes ranged from 0.02 to $0.58 \mathrm{mSv}$ per 100 block hours ${ }^{(2)}$. Thus, a crew who worked 700 block hours per year on any combination of these different

(2) The block hours of flight begin when the aircraft leaves the blocks before takeoff and end when it reaches the blocks after landing. 
flights would receive an annual radiation dose of between 0.14 and $4.06 \mathrm{mSv}$. Bottollier-Depois (Bottollier-Depois, 1997) studied French airlines and obtained similar results.

On supersonic transport, effective dose rates increase up to $10-12 \mu \mathrm{Sv} \mathrm{h}^{-1}$ at higher altitudes. Flights at these altitudes are shorter, however, and crews work only about 300 block hours per year, so that the annual effective dose is quite similar to that received by airplane crews on subsonic aircrafts. Bottollier-Depois (Bottollier-Depois, 1997) took measurements on board the Concorde, flying at altitudes above $15 \mathrm{~km}$, and estimated mean annual doses between $2.6 \mathrm{mSv} \mathrm{h}^{-1}$ (in 1991 = during maximum solar activity) and $3.4 \mathrm{mSv} \mathrm{h}^{-1}$ (in $1996=$ during minimum solar activity).

ICRP also noted that some passengers travelling on business roughly 200 hours per year in conventional jet aircraft are likely to receive effective dose of about $1 \mathrm{mSv}$.

In its publication 75 (ICRP, 1997), the Commission also noted that the exposure of jet air crew should be treated as occupational exposure. It is recommended that the annual effective doses should be derived from the flying time and typical effective-dose rates for the relevant routes and that there is no need to consider any other practical control measure.

\section{Conclusion}

General principles for the radiation protection of workers have recently been extensively revised. In particular, ICRP has addressed the problem of exposure to natural sources of radiation incurred at work as the result of "situations that can reasonably be regarded as being the responsibility of the operating management". Some practical guidance has been given by ICRP for deciding whether exposure from natural sources should be included as part of occupational exposure. In any case, such occupational exposure to natural sources should be excluded from the general system of protection and treated separately from artificial radiation sources. Exposure to radon, to materials with elevated levels of natural radionuclides and to cosmic radiation in jet aircraft have been clearly identified as subject to control by regulatory authorities. Other situations for which regulation and control are necessary are not as well-identified and need further development.

The problem has been treated in the European Directive in Title VII "Significant increase in exposure due to natural radiation sources". This Title states that each Member State shall ensure the identification, by means of surveys or by any other 
appropriate means, of work activities which may be of concern. Once these activities have been identified and declared as relevant to control, the Member States shall require to set-up appropriate means for monitoring exposure and, as necessary, for reducing it.

To assess the real extent of the problem, a sound analysis of the issue, beginning by a better identification of the different types of workplaces concerned, must be performed in many countries. If it is found that control at these workplaces is justified, the next step should be to develop adequate monitoring of workers and procedures to reduce their exposure to below action levels, according to the optimisation principle.

\section{REFERENCES}

Bernhard S. (1995) Cas des installations d'extraction et de traitement du minerai d'uranium. AIEA training course, Saclay.

Bottollier-Depois J.F. (1997) Évaluation de l'exposition au rayonnement cosmique à bord d'avion long courrier. Rapport IPSN SDOS/97-01.

Brown L.D. (1990) Control of occupational exposure to radon in the workplace. Proc. of 29th Hanford Symposium on Health and the Environment - Indoor radon and lung cancer: reality or myth? (F. T. Cross, Ed.) Battelle Press, Columbus, Ohio, pp. 27-35.

Clarke R. (1996) Control of exposure to natural radiation: an ICRP perspective. Environment Internationa!, vol. 22, Suppl. 1, pp. S105-S110.

Commission of the European Communities (1993). Principles and methods for establishing concentrations and quantities (exemption values) below which reporting is not required in the European Directive.CEC Radiation Protection-65. Doc. XI-028/93.

Duffy J.T., Madden J.S., Mackin G.M. McGarry A.T. and Colgan P.A. (1996) A reconnaissance survey of radon in show cave in Ireland. Environ. Int. 22, Suppl. 1, pp. S415-S423.

European Union (1996) Council Directive 96/29/EURATOM of 13 May 1996 laying down basic safety standards for the protection of the health of workers and the general public against the dangers arising from ionizing radiation. Official Journal of the European Communities $n^{\circ} \mathrm{L} 159 / 14$.

ICRP (1991) 1990 Recommendations of the International Commission on Radiological Protection. ICRP Publication 60, Vol 21, No 1-3, Pergamon Press, Oxford.

ICRP (1993) Protection Against Radon-222 at Home and at Work. ICRP Publication 65, Vol 23, N², Elsevier, Oxford.

ICRP (1997) General Principles for the Radiation Protection of Workers. ICRP Publication 75, Vol 27, $\mathrm{N}^{\circ} 1$, Elsevier, Oxford.

IAEA (1994) International Basic Safety Standards for Protection Against Ionizing Radiation and Safety of Radiation Sources. Safety Series N ${ }^{\circ} 115-\mathrm{I}$, Vienna. 


\section{A. RANNOU}

Lettner H., Hubmer A.K., Rolle. R. and Steinhausler F. (1996) Occupational exposure to radon in treatment facilities of the radon-spa Badgastein, Austria. Environ. Int. 22, Suppl. 1, pp. S399S407.

O'Brien K., Friedberg W., Sauer H.H., Smart D.F. (1996) Atmospheric cosmic rays and solar energetic particles at aircraft altitudes. Environ. Int. 22, Suppl. 1, pp. S9-S44.

Organisation for Economic Co-operation and Development, Nuclear Energy Agency and International Atomic Energy Agency (1994) Uranium 1993 - Resources, Production and Demand. OECD, Paris.

Sciocchetti G., Tosti S., Baldassini P.G., Sarao R. and Soldano E. (1990) Dose assessment of population groups exposed to elevated radon levels in radioactive spas. Proc. of 29th Hanford Symposium on Health and the Environment - Indoor radon and lung cancer: reality or myth ? (F.T. Cross Ed.) pp. 37-49.

Solomon S.B., Langroo R., Lyons R.G. and James J.M. (1996) Radon exposure to tour guides in Australian show cave. Environment International, vol. 22, Suppl. 1, pp. S409-S413.

Szerbin P. (1996) Natural radioactivity of certain spas and caves in Hungary. Environ. Int., 22, Suppl. 1, pp. $\$ 389-\$ 398$.

United Nations Scientific Committee on the Effects of Atomic Radiation (1993) Sources and Effects Of Ionizing Radiation, UNSCEAR 1993 Report to the General Assembly with Scientific Annexes, United Nations, New York. 